\section{Discussion and Conclusion}

In discussing the economic status of the Great Horned Owl, Taverner (1934) recorded that of 110 stomachs examined, 31 contained poultry or game birds, 8 other birds, 13 mice, 65 other mammals, a scorpion, one fish, and 10 insects. Taverner considered this evidence against the owl. On the other hand, Brandt (1951) recorded that the commonest food constituents in the nests of this bird were cottontail rabbits, other small mammals, and occasionally birds. It would appear that the economic status of the Great Horned Owl, as Taverner says, "depends upon where it lives." An editorial note in the Blue Jay (18:16) mentions that Great Horned Owls in Montana were found to feed magpies to their young, and consequently were beneficial in controlling magpies.

Of the 36 owls that yielded data in this study, only one had eaten poultry, three had taken game birds, and one a Hairy Woodpecker. Thirtyone of the birds had taken no food that could in any way be regarded as economically useful to man. Of the 36 total, 29 had foraged successfully after mice, pocket gophers and crows, creatures that man regards as economically harmful. The only conclusion that I can draw from the data presented is that the Great Horned Owl, economically, is decidedly more beneficial than harmful.

\section{LITERATURE CITED}

BRANDT. H. 1951. Arizona and its bird life. The Bird Research Foundation, Cleveland, Ohio.

HOLLAND, G. P. 1954. The Crow Flea (Cerotophyllus rossittensis, Dampf, in North America (Siphonaptera Ceratophyllidae). The Canadian Entomologist, 86:334-336.

PORTMAN, $A$. and $W$. STINGELIN. 1961. The cortrol ne:vous system. Ch. XIII of Biology and comparative physiology of birds, ed. by A. J. Marshall. New York. Academic Press. TAVERNER, P. A. 1934. Birds of Canada. King's Printer, Ottawa.

\title{
Common Tern Recovery From Cook Islands
}

\section{by C. Stuart Houston, Saskatoon}

Although the Common Tern (Sterna hirundo) is known to winter at New Guinea and the Solomon Islands in the southwest Pacific these birds are presumed to have migrated from northeastern Asia (Kamchatka to Sakhalin Islands). There were apparently no specimens or sight records from the central Pacific until this past year when two banding recoveries were obtained.

On November 26, 1960, a bird wearing band 523-60398 was found in the lagoon near the beach at Ureia, Aitutaki Island, in the Cook Islands group administered by New Zealand. The band was found by Roi Marama and shown to Mr. P. Pamatatau of the Resident Agent's Office of the Cook Islands Administration, who reported it to the U.S. Fish and Wildlife Service, Washington, D.C. Unfortunately the band was not submitted and was lost by Mr. Marama in the several months that elapsed before my letter requesting the band could reach him. However, Mr. Pamatatau assured me that "It is proved correct by me and other official persons that the in- scription on the band is correct unless one figure is wrong which should be 525-60398 instead of 523-60398." (Note: 525 indicates a size 5 band and 523 a size 3 ). I then sent $\mathrm{Mr}$. Pamatatau sample bands of size 3 and size 5 to enquire which size the band was-he returned these with the inscription "this is it" opposite the size 3 band and "this is NOT" beside the size 5 band. Since there is a marked difference in size between a size 3 and size 5 band, there seems little doubt that it was the former. 523-60398, a nestling Common Tern, was banded by the writer at $51^{\circ} 21^{\prime} \mathrm{N}$., $105^{\circ} 15^{\prime} \mathrm{W}$., Last Mountain Lake, eight miles east of Imperial, Sask., on July 8, 1956.

The Cook. Islands are approximately 1800 miles northeast of New Zealand and between 2800 and 3000 miles south of the Hawaiian islands. The distance from Saskatchewan to the Cook Island is about 6000 miles. This is the farthest distance travelled by any of the 1134 recoveries received to date from over 20,000 birds banded by the writer. Of 350 Com- 


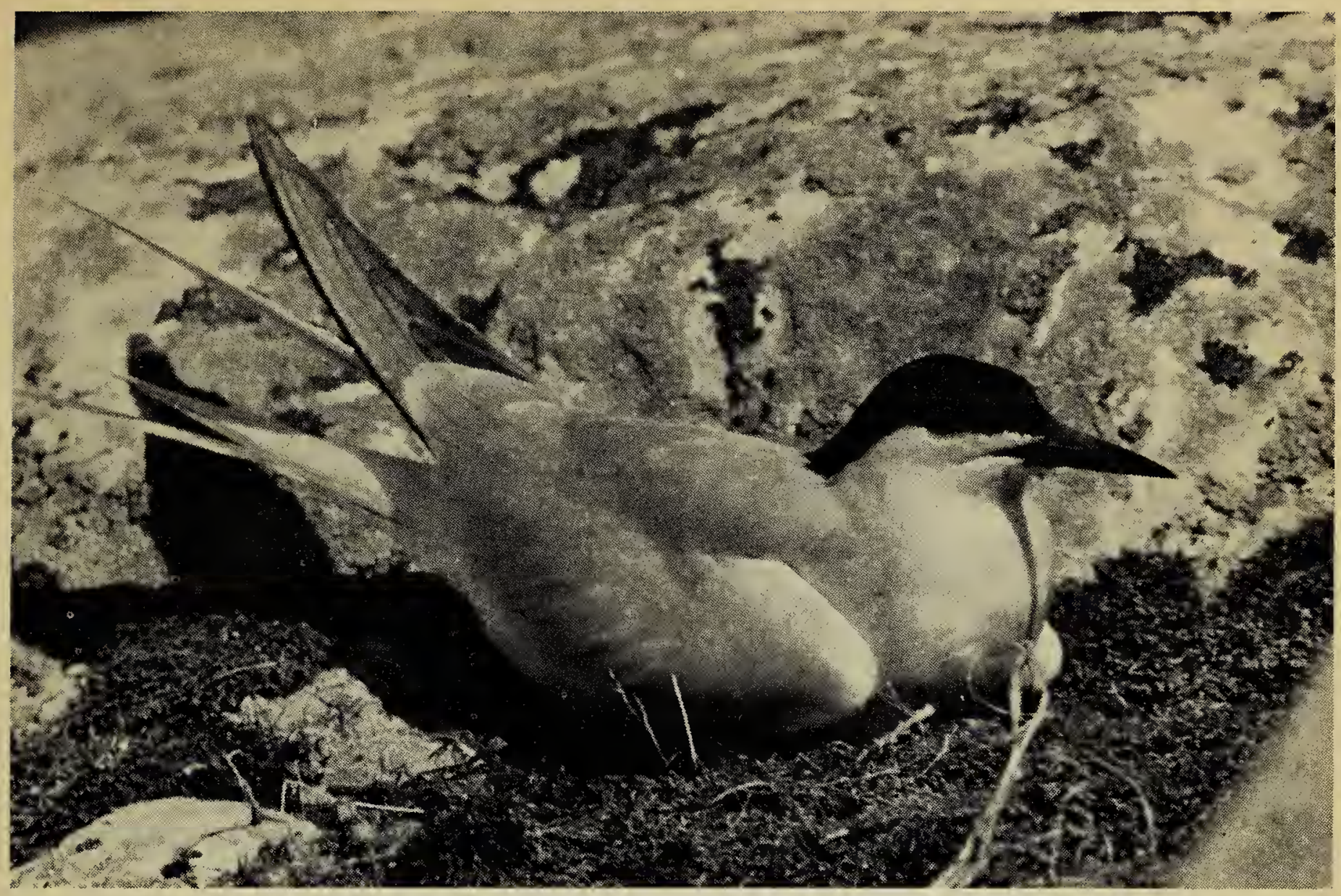

Common Tern.

Photo by F. W. Lohrman

mon Terns banded prior to 1961 , the only previous recovery was from a tern banded at Redberry Lake in 1958 and caught in a fish net in the state of Colima on the west coast of Mexico, six and one-half months later.

The above record was soon followed by the second Common Tern record from the central Pacific-also a banded bird, banded by another medical doctor! A nestling Common Tern, 543-87827, banded on June 27, 1960, by Dr. F. E. Ludwig at Grassy Island, Lake Huron, near Alpena, Michigan, was shot by Raymond J. Kramer, wildlife biologist for the state of Hawaii, on April 25, 1961. The local Audubon Club at Honolulu had been observing what they thought was Black-naped Tern at Paiko Lagoon at the extreme southerly tip of the island of Oahu. With the permission of the President of the Audubon Club and the Director of the Department of Conservation of the State of Hawaii, Mr. Kramer went there to collect the supposed Asiatic stray. Imagine the surprise when close examination proved it to be a banded Common Tern- a new species for the state. This Common Tern is now mounted and on display, still wearing its band, in the Bishop Museum in Honolulu.

Dr. Ludwig writes that he has had several recoveries from Michigan birds from the western shore of South America, panticularly from Ecuador, Columbia and Peru. He feels that his bird probably migrated to that area, but instead of migrating back to Michigan in the spring of 1961 , made a left turn (not a common turn!) and ended up in Hawaii.

Even though wildiife statisticians may prefer large and statistically significant numbers of recoveries and decry random banding that fails to produce such numbers, yet this is anather example of individual recoveries that can be of considerable ornithological initerest.

EDITOR'S NOTE: Another interesting example of long-range migration comes from a U.S. Fish and Wildlife Service release (April 6 , 1962) telling of far-travelling birds crossing the Iron Curtain. Since 1939 when a Russianbanded bird was recovered in California, over 100 American-banded birds have been recovered in Russio and over 75 Russian-bonded birds have been taken in Alaska and other states. One of these was a crane, the Common Crane of Europe and Asia, which visited the Bitter Lake Notional Wildlife Refuge near Roswell, New Mexico, on March 10, 1961, the fifth record for this species in North America. Two and a half months later, a Lesser Sandhill Crane banded at the Bitter Lake Refuge, January 29, 1960, was reported on a "state" visit at Krasneno, Russia, . about 5500 air miles from Bitter Lake. 